\title{
CYTOGENETIC EFFECTS INDUCED BY PAPER MILL EFFLUENT AND DOMESTIC SEWAGE IN MICE TEST SYSTEM
}

\author{
RAJESH PAUL ${ }^{1} \&$ JASHODEB ARJUN ${ }^{2 *}$ \\ ${ }^{1}$ Associate Professor, Department of Zoology, Lumding College, Lumding, Assam, India \\ $2^{*}$ Research Scholar, Lumding College, Lumding, Assam, India
}

\begin{abstract}
Present investigation reported an analytical work performed to test potential mutagenic effects of Paper Mill Effluent (PME) from Cachar, which is the only paper mill in Barak valley region and City Domestic Sewage (DS) from Cachar district, Assam, India, in mice test system. Bone marrow Micronucleus (MN) assay was preferred to analyse the toxicity induced by PME and DS. Mice were exposed intraperitoneally to $10 \%, 25 \%$ and $50 \%$ concentrations of both the effluents for $24 \mathrm{~h}-72 \mathrm{~h}$. All three acute doses showed not only induction of MN but also increase in the frequency of micronucleated polychromatic erythrocytes (PCEs) followed by three consecutive days. Current investigation was conducted in fish Channa punctatus and remarkable induction of toxicity was recorded by using Micronucleus assay, so to analyse the level of toxicity in other test models the work was repeated in mice and supportive data was received. By applying Micronucleus assay, DS was found to have more effect in comparison to PME. We concluded that both PME and DSholdmutagenic potential. However, Domestic Sewage needs more careful pretreatment before release into open water bodies.
\end{abstract}

ABBREVIATION: PME: Paper Mill Effluent; DS: Domestic Sewage, MMC: Mitomycin C

KEYWORDS: Paper Mill Effluents, Domestic sewage, Micronucleus assay

Received: Nov 01, 2020; Accepted: Nov 21, 2020; Published: Jan 23, 2021; Paper Id.: IJEEFUSDEC20203

\section{INTRODUCTION}

Untreated release of around $80 \%$ of the world's wastewater into aquatic water resources is a major matter of concern which returns back into environment, polluting rivers, lakes and ponds. Widespread problem of water pollution isjeopardizing our health. Water from surface that includes river and lakes, ground water, marine and coastal water support all living creatures including human beings. Untreated waterkills more people every year than civil wars and any other forms of violence as a whole. Indian government had already undertaken many projects and measures for the safety of water bodies from hazardous exposure of industrial discharges. Many public awareness programmes have been conducted so that people does not depend on such polluted water bodies for their usage and for domesticated animals. Not to our surprise, Indian constitution enlists many laws and rights for safety of aquatic bodies and says that country people have the right to get disease free drinking water. Article 21 of Indian constitution embodies right to pure drinking water. Countrycitizens must take serious initiatives to protect every environmental resource including wildlife and water bodies and which directly or indirectly is necessary for their livelihood. The quality of water is thus of vital concern as it directly influences human health. But with the prolonged liberation of untreated effluents and sewages in water bodies, maintenance of water quality has become a big threat.Surface water receives huge bulk of solid and liquid waste from industrial, agricultural, and domestic sources, 
including municipal sewage treatment plants. In past hundred years more and more industries have developed all over the country and most of the discharges find their ways into these water bodies. Untreated domestic sewage including house hold, hospitality releases, municipal outflows, agricultural discharges including pesticides , fungicides and thousands of chemical discharges from various sources are entering the water bodies whichalso finds its way in local water bodies (Mayur C Shah, 2008).Such mutagenic compounds, increases the potentiality of hazardous environmental mixture that can have adverse effects on life on earth (Dearfield et al., 2002).

Evaluation of MN frequency has been recommended by the regulatory agencies to be conducted as a part of product safety assessment (Krishna et al, 2000). Micronucleus (MN) test is regarded as one of the most popular cum reliable assay serving as an index of cytogenetic damage (Schmid, 1975; Heddle et al., 1991).This assay helps to assess dose response relationships of both DNA reactive and non- reactive genotoxins (Al-Sabti et al., 1994; Pacheco and Santos, 1999; Gravato and Santos, 2003, Sharma and Chadda, 2017).To test chromosomal damage in vivo, mice bone marrow MN assay has been used extensively (Tice et al, 1994).MN assay can detect spindle poisons too; it can also be used to differentiate $\mathrm{MN}$ and $\mathrm{MN}$ without centromere.

As a remarkable and trustworthy experimental mammals, Swiss albino micereports certain advantages like welldefined karyotype and chromosome number $(2 n=40)$ which is similar to that of human. It has been successfully used for cytogenetic studies throughout previous years (Celik et al., 2003; Karabay and Oguz, 2005). Considering the above aspects of water pollution, thestudy was undertaken to investigate the impact of water pollution created by industrial as well as domestic sewages by using Swiss albino mice as the test model. Eukaryotic mutagenicity assay namely the micronucleus $(\mathrm{MN})$ test in mouse bone marrow cells was used forevaluation of genotoxic potentialby effluent and sewage from Cachar district, Assam.

\section{MATERIALS AND METHODOLOGY}

\subsection{Site of Sampling Site and of Water Samples}

Highlighted objective was to evaluate the acute toxicity of a paper mill effluent of Barak valley region and to compare the results with city domestic sewage of Cachar, Assam on the behavioural responses of a regularly consumed freshwater fish Channa punctatus. Raw effluent sample was collected from the outlet discharge pipes in the local river Barak in plastic containers. Domestic sewage was collected from the municipal discharge outlets. The $\mathrm{pH}$ was measured on the very collection spot. Samples were brought to laboratory and to prevent further microbial growth were stored at $-20^{\circ} \mathrm{C}$.

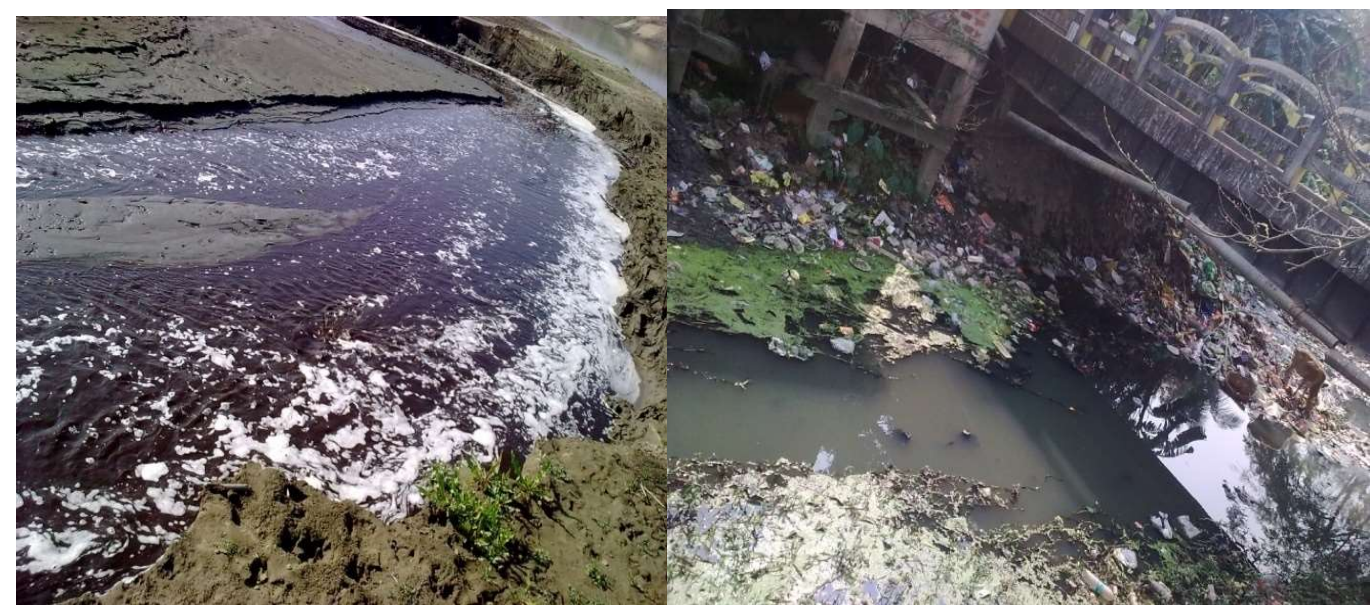

Figure 1: Sampling site of Paper Mill Effluent and Domestic Sewage 


\subsection{Test Animals}

Organisms are frequently used to study the intrinsic capacity of substances dissolved in effluents and domestic sewages which produces injuries under exposure. This study has Institutional animal ethics clearance. Swiss albino mice (Mus musculus) of age group of 10-12 weeks and weighing 20-25 g obtained from Pasture Institute, Shillong, India. The animals were maintained in closely inbred colony under conventional pathogen free laboratory conditions where room temperature was maintained of $25.0 \pm 5.0{ }^{\circ} \mathrm{C}$ following $12 \mathrm{~h}$ dark and $12 \mathrm{~h}$ light cycles. Standard food pellets and water were given to all test groups after regular intervals.

\subsection{Doses}

Treatment of $10 \%, 25 \%$ and $50 \%(\mathrm{v} / \mathrm{v}$, effluent/distilled water) were given to mice $(\mathrm{n}=4)$ with a constant volume of 0.3 $\mathrm{ml} /$ mouse of both PME and DS. Mitomycin C (2 mg/kg) was selected for positive control. Untreated control mice were treated with equal volumes of isotonic saline $(0.9 \% \mathrm{NaCl})$. All doses were given intraperitoneally (i.p.). Test animals showed highest dose tolerance without any visible symptoms.

\subsection{Micronucleus Assay}

A micronucleus is a cytoplasmic body which is formed during anaphase of mitosis or meiosis. Micronuclei are cytoplasmic bodies, which if formed leads to daughter cell lacking either one part or whole of a chromosome. During induction of a genetic damage either one or more micronuclei may get formed. This test helps to evaluate the extent of chromosomal damage caused due to exposure to genotoxic agents.During the present piece of work, Micronucleus assay was conducted followed by theprotocol of Schmid (1976) with minor modifications. After the desired exposure period, animal sacrifice was done through cervical dislocation. The bone marrow cells were collected in $0.56 \% \mathrm{KCl}\left(37^{\circ} \mathrm{C}\right)$ and slides were prepared and air dried .Fixation was done in methanol for 10 minutes. Staining was performed with $5 \%$ buffered Giemsa (pH 7.0). The slides were mounted with DPX mountant. The PCEs stain light blue whereas NCEs stain light orange to pale yellow. At least 2000 cells including PCEs, NCEs were studied to check the presence of MN under light microscope 1000X magnification.

\subsection{Scoring Criteria Referred for Micronuclei detection}

Following criteria for identification were used (Al-Sabti and Matcalfe, 1995):-

- Size of MN detected must be smaller than one third of the main nuclei,

- The main nuclei and micronuclei must be separated clearly from each other,

- The original nuclei and MN must be on the same plane of focus and have same colour.

- The original nucleus and MN have same intensity.

\section{STATISTICAL ANALYSIS}

Data obtained were presented as Mean $\pm \mathrm{SD}$. Data was analysedfollowed by One Way ANOVA and were expressed as percentage frequency for MN test.Significance at different dose levels was studied by using Graph Pad Prism Software (Graph Pad Inc., San Diego, CA, USA). 


\section{RESULTS}

Table 1:Paper Mill Effluent induced micronucleated bone marrow cells in mice

\begin{tabular}{|c|c|c|c|c|c|c|c|}
\hline $\begin{array}{l}\text { Dose } \\
(\mathrm{mg} / \mathrm{kg})\end{array}$ & Concentrations & $\begin{array}{l}\text { Duration } \\
\text { (Hrs.) }\end{array}$ & Route & $\begin{array}{l}\text { TOTAL } \\
\text { PCE/n }\end{array}$ & $\begin{array}{l}\% \text { PCEs } \\
\text { With MN } \\
(\text { mean } \pm \text { S.D) }\end{array}$ & $\begin{array}{l}\% \text { NCEs } \\
\text { With MN } \\
(\text { mean } \pm \text { S.D) }\end{array}$ & $\begin{array}{l}\text { PCE/NCE } \\
(\mathrm{MEAN} \pm \text { S.D) }\end{array}$ \\
\hline \multirow[t]{3}{*}{ Control } & \multirow[t]{3}{*}{--- } & 24 HRS. & i.p & $6008 / 4$ & $0.12 \pm 0.05$ & --- & $2.79 \pm 0.09$ \\
\hline & & 48 HRS. & i.p & $6023 / 4$ & $0.15 \pm 0.02$ & $0.04 \pm 0.07$ & $2.5 \pm 0.44$ \\
\hline & & 72 HRS. & i.p & $6015 / 4$ & $0.24 \pm 0.04$ & $0.09 \pm 0.07$ & $2.5 \pm 0.44$ \\
\hline \multirow[t]{3}{*}{ MMC } & \multirow[t]{3}{*}{---} & 24 HRS. & i.p & $6012 / 4$ & $1.07 \pm 0.11$ & $1.27 \pm 0.12$ & $4.83 \pm 0.01$ \\
\hline & & 48 HRS. & i.p & $6032 / 4$ & $1.82 \pm 0.08$ & $3.13 \pm 0.21$ & $4.92 \pm 0.01$ \\
\hline & & 72 HRS. & i.p & $6010 / 4$ & $1.92 \pm 0.09$ & $3.34 \pm 0.23$ & $4.92 \pm 0.01$ \\
\hline \multirow{9}{*}{$\begin{array}{l}\text { Paper } \\
\text { Mill Effluent }\end{array}$} & $10 \%$ & 24 HRS. & i.p & $6021 / 4$ & $0.24 \pm 0.08^{c}$ & $0.14 \pm 0.12^{* *} \cdot \mathrm{bc}$ & $2.8 \pm 0.02^{\mathrm{c}}$ \\
\hline & $25 \%$ & 48 HRS. & i.p & $6030 / 4$ & $0.45 \pm 0.15^{\mathrm{c}, \mathrm{a}, \mathrm{b}}$ & $0.23 \pm 0.07^{\mathrm{a}}$ & $2.94 \pm 0.01$ \\
\hline & $50 \%$ & 72 HRS. & i.p & $6025 / 4$ & $1.27 \pm 0.14 * * *, \mathrm{c}, \mathrm{a}$ & $0.19 \pm 0.07^{\mathrm{a}}$ & $2.99 \pm 0.01^{\mathrm{b}}$ \\
\hline & $10 \%$ & 24 HRS. & i.p & $6046 / 4$ & $1.23 \pm 0.17 * * *, \mathrm{c}$ & $0.58 \pm 0.07$ & $3.22 \pm 0.02^{*}$ \\
\hline & $25 \%$ & 48 HRS. & i.p & $6024 / 4$ & $0.92 \pm 0.11 * * *, \mathrm{c}, \mathrm{a}$ & $0.76 \pm 0.06$ & $3.52 \pm 0.08^{* * *} \mathrm{c}, \mathrm{b}$ \\
\hline & $50 \%$ & 72 HRS. & i.p & $6028 / 4$ & $1.71 \pm 0.17 * * *, \mathrm{c}, \mathrm{a}$ & $1.29 \pm 0.25^{\mathrm{b}, \mathrm{a}}$ & $3.59 \pm 0.01^{* * *} \mathrm{c}$ \\
\hline & $10 \%$ & 24 HRS. & i.p & $6028 / 4$ & $2.01 \pm 0.06 * * *, \mathrm{c}$ & $1.94 \pm 0.55^{* * *} . \mathrm{c}$ & $3.53 \pm 0.1^{* * *} \mathrm{c}$ \\
\hline & $25 \%$ & 48 HRS. & i.p & $6022 / 4$ & $2.18 \pm 0.2^{* * *, \mathrm{c}}$ & $2.38 \pm 0.32^{* * * . c}$ & $3.77 \pm 0.05^{* * * \mathrm{c}}$ \\
\hline & $50 \%$ & 72 HRS. & i.p & $6021 / 4$ & $2.9 \pm 0.14 * * *, \mathrm{c}$ & $3.48 \pm 0.43^{* * *, c}$ & $3.8 \pm 0.02^{* * *} \mathrm{c}$ \\
\hline
\end{tabular}

Table 2: Domestic Sewage induced micronucleated bone marrow cells in mice.

\begin{tabular}{|c|c|c|c|c|c|c|c|}
\hline $\begin{array}{l}\text { Dose } \\
(\mathrm{mg} / \mathrm{kg})\end{array}$ & Concentrations & $\begin{array}{l}\text { Duration } \\
\text { (Hrs.) }\end{array}$ & Route & $\begin{array}{l}\text { TOTAL } \\
\text { PCE/n }\end{array}$ & $\begin{array}{l}\text { \%PCEs } \\
\text { With MN } \\
(\text { mean } \pm \text { S.D) }\end{array}$ & $\begin{array}{l}\text { \%NCEs } \\
\text { With MN } \\
(\text { mean } \pm \text { S.D) }\end{array}$ & $\begin{array}{l}\text { PCE/NCE } \\
(\mathrm{MEAN} \pm \text { S.D) }\end{array}$ \\
\hline \multirow[t]{3}{*}{ Control } & \multirow[t]{3}{*}{--- } & 24 HRS. & i.p & $6008 / 4$ & $0.12 \pm 0.05$ & --- & $2.79 \pm 0.09$ \\
\hline & & 48 HRS. & i.p & $6023 / 4$ & $0.15 \pm 0.02$ & $0.04 \pm 0.07$ & $2.5 \pm 0.44$ \\
\hline & & 72 HRS. & i.p & $6015 / 4$ & $0.24 \pm 0.04$ & $0.09 \pm 0.07$ & $2.5 \pm 0.44$ \\
\hline \multirow[t]{3}{*}{ MMC } & \multirow[t]{3}{*}{---} & 24 HRS. & i.p & $6012 / 4$ & $1.07 \pm 0.11$ & $1.27 \pm 0.12$ & $4.83 \pm 0.01$ \\
\hline & & 48 HRS. & i.p & $6032 / 4$ & $1.82 \pm 0.08$ & $3.13 \pm 0.21$ & $4.92 \pm 0.01$ \\
\hline & & 72 HRS. & i.p & $6010 / 4$ & $1.92 \pm 0.09$ & $3.34 \pm 0.23$ & $4.92 \pm 0.01$ \\
\hline \multirow{9}{*}{$\begin{array}{l}\text { Domestic } \\
\text { Sewage }\end{array}$} & $10 \%$ & 24 HRS. & i.p & $6015 / 4$ & $0.99 \pm 0.04 * * * \mathrm{c}, \mathrm{b}$ & $0.83 \pm 0.25$ & $3.92 \pm 0.05^{* * * c}$ \\
\hline & $25 \%$ & 48 HRS. & i.p & $6025 / 4$ & $1.37 \pm 0.09 * * * \mathrm{c}$ & $1.83 \pm 0.24^{* * *, c}$ & $3.96 \pm 0.04^{* * * \mathrm{c}}$ \\
\hline & $50 \%$ & 72 HRS. & i.p & $6016 / 4$ & $1.57 \pm 0.22 * * * \mathrm{c}$ & $2.35 \pm 0.23^{* * *, c}$ & $4.05 \pm 0.07^{* * * \mathrm{c}}$ \\
\hline & $10 \%$ & 24 HRS. & i.p & $6012 / 4$ & $1.92 \pm 0.11 * * * \mathrm{c}$ & $2.58 \pm 0.24^{* * *}, \mathrm{c}$ & $4.2 \pm 0.01^{* * * \mathrm{c}}$ \\
\hline & $25 \%$ & 48 HRS. & i.p & $6020 / 4$ & $2.74 \pm 0.16^{* * * \mathrm{c}}$ & $3.56 \pm 0.56^{* * *, c}$ & $4.38 \pm 0.04^{* * *} \mathrm{c}$ \\
\hline & $50 \%$ & 72 HRS. & i.p & $6036 / 4$ & $2.59 \pm 0.06 * * * \mathrm{c}$ & $4.76 \pm 0.29^{* * *, c}$ & $4.61 \pm 0.1^{* * *} \mathrm{c}$ \\
\hline & $10 \%$ & $24 \mathrm{HRS}$. & i.p & $6012 / 4$ & $2.17 \pm 0.09 * * * \mathrm{c}$ & $3.62 \pm 0.27^{* * *, c}$ & $4.99 \pm 0.07^{* * * \mathrm{c}}$ \\
\hline & $25 \%$ & 48 HRS. & i.p & $6038 / 4$ & $3.47 \pm 0.07 * * * \mathrm{c}$ & $5.15 \pm 0.28^{* * *}, \mathrm{c}$ & $5.1 \pm 0.05^{* * *} \mathrm{c}$ \\
\hline & $50 \%$ & 72 HRS. & i.p & $6025 / 4$ & $2.9 \pm 0.09 * * * \mathrm{c}$ & $4.99 \pm 0.40^{* * *, c}$ & $4.98 \pm 0.04^{* * * \mathrm{c}}$ \\
\hline
\end{tabular}

When compared PME and DS with Control When compared in between PME and DS

$\mathrm{P}<0.05=*, \mathrm{P}<0.01=* *, \mathrm{P}<0.001=* * * \quad \mathrm{P}<0.05=\mathrm{a}, \mathrm{P}<0.01=\mathrm{b}, \mathrm{P}<0.001=\mathrm{c}$ 


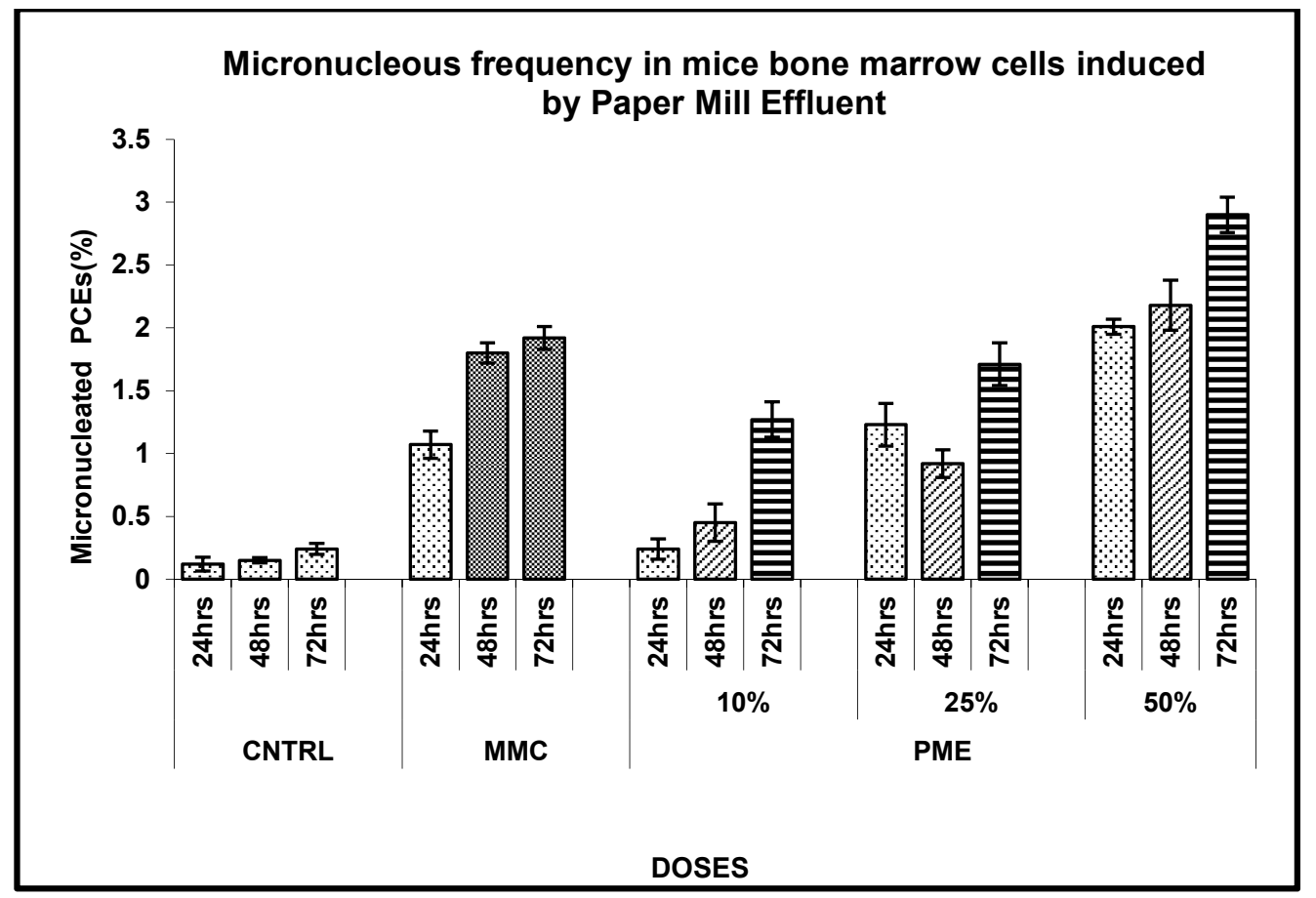

Graph 1:Paper Mill Effluent induced micronucleated bone marrow cells in mice

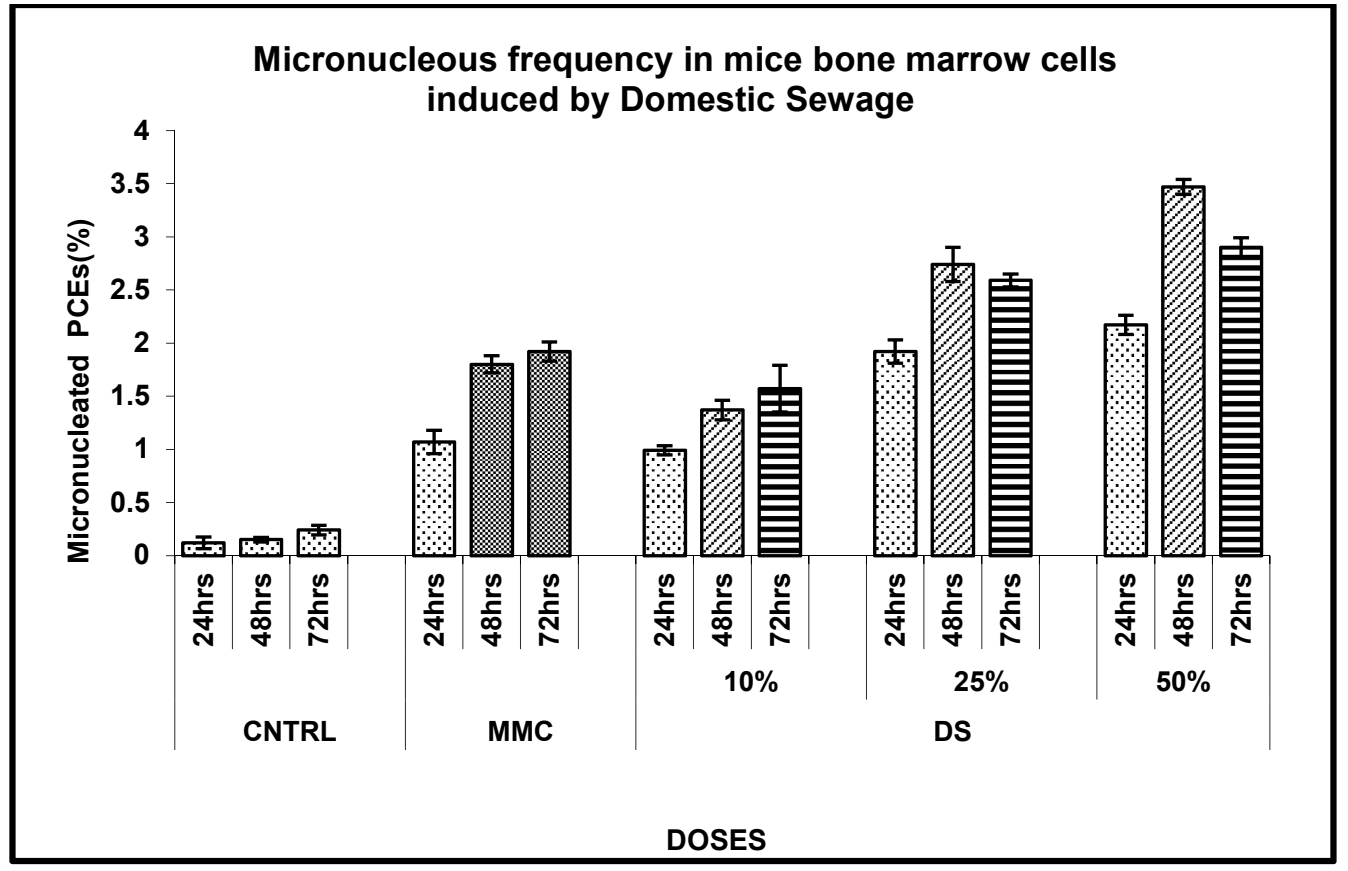

Graph 2: Domestic Sewage induced micronucleated bone marrow cells in mice

\section{DISCUSSIONS}

Micronucleus test is effective in toxicological screening for potential genotoxic compounds. It's now recognised as one of the most successful and reliable assays for genotoxic carcinogens.Mouse bone marrow or mouse peripheral blood.is considered best for undergoing the assay. When a bone marrow erythroblast develops into a polychromatic erythrocyte, the main nucleus gets extruded and any micronucleus that has been formed due to toxicity inoculatedmay remain behind in the anucleated cytoplasm. Induction of $\mathrm{MN}$ or increase in the frequency of micronucleated polychromatic erythrocytes in 
treated animals is an indicator of induced chromosome damage.

We have already tested and reported in previous works,the effluent vice versa sewage quality, followed by many physico chemical parameters where both PME and DS reported their toxic potential. Later we tested the exploration of microbial diversity in nutrient medias when exposed to different concentrations of PME and DS. Based on supportive results mutagenic effects of PME and DS were tested in fish test model where both effluents have showed remarkable results. To explore the effects of PME and DS of Cachar district in mammalian model present investigation was conducted where, PME have been observed to induce micronucleus in mice bone marrow cells. MNwere recorded to increasewith increase in concentrations of PME. Intraperitoneal treatment of PME after $24 \mathrm{~h}, 48 \mathrm{~h}$ and $72 \mathrm{hrs}(\mathrm{p}<0.05, \mathrm{p}<0.001)$ submitted significant increase in the frequency of micronucleated PCEs. The PCE/NCE ratio also increased favouring dose dependent and time dependent response for PME .Unlike paper mill effluent, domestic sewage of Barak valley region also lead to induction of micronuclei which reported significant $(p<0.01, p<0.001)$ increase of MN frequency not only for dose response but also the frequency of micronucleated PCEs increased supporting the time dependent response for three consecutive days. Highly significantly increase of PCE/NCE ratio was observed in case of domesticated sewage $(p<0.001)$.The frequency of both micronucleated PCEs and PCE/NCE ratio induced by DS when compared with that of PME, DS expressed remarkable genotoxic effect in comparison to PME. Domestic sewage can be expected to bear more carcinogenic potential as it is a mixture of domestic waste, hospitality releases, dyes, animal excreta, pesticides and many more. Hence, it can possess better carcinogenic potentialitiescausing more damage in fish as well as mice or other test models. Long term genotoxicity study in present work has been proved important for receiving visible results against the mutagenic potentials of industrial effluents and domestic sewages.

The possible mechanism behind the induction of abnormalities in mouse bone-marrow cells might be the absorption of effluent and sewages in the cells which caused change in $\mathrm{pH}$ within and outside cells. As a result the enzymatic activities may get disturbed.Due to carcinogenic effect of industrial effluent and the selected sewage free radicals might got formed either through auto-oxidation, pharmacodynamics or enzyme-catalysed oxidation of electrophilic components present in the effluent and sewage.The free radicals thus formed could react with proteins and enzymes involved in the DNA repair mechanism resulting in increasing the frequency in DNA damage.Hence, it may be considered that the reactions of DNA and free radicals, have resulted in production of DNA adducts, which are by nature mutagenically potent and contributors to the etiology of genetic diseases (Flora et al, 1994).

\section{CONCLUSIONS}

Industrial and domesticated discharges to a tremendous extent causepollution in marine environment. Cachar paper Mill Effluent and domestic sewage is a major threat for local people as they with their domestic animals fully depend on water of Barak River for livelihood. In support to previous researches our work also supports this fact.Hence, from health perspective proper measures should be adapted by government and industrial management of release the waste to other dumping grounds .Sewage should also be treated before release in water bodies. Thus water quality maintenance and management demands absolute attention.So, we are hopeful that adequate measures will be undertaken from safety point of view.

\section{REFERENCES}

1. Akintonwa, A; Awodele, O; Olofinnade, A. T; Anyakora, C; Afolayan, G. O and Coker, A.B, 2009Assessment of the Mutagenicity of Some Pharmaceutical Effluents. American Journal of Pharmacology and Toxicology. 4(4), 142-148. 
2. Albertini, R.J; Aderson, D; Dauglas, G.R; Hagmar,L. Hemminki, K; Merlo,F; Natarajan, H; Norppa, A.T; Shuker, D. E ;Tice, G. R; Waters, M. D; Aitio, A, 2000 IPCS guidelines for the monitoring of genotoxic effects of carcinogens in human. Mutat. Res., 463, 111-172.

3. Alimba, C.G; Bakare, A. A. and Latunji, C. A., 2006 Municipal landfill leachates induced chromosome aberrations in rat bone marrow cells.African Journal ofBiotechnology, 5 (22) ,2053-2057.

4. Celik, A; Mazmanci, B; Camlica, Y; Askin, A,2003 Cytogenetic effects of lambda-cyalothrin on Wistar rats bone marrow. Mutat. Res., 539, 91-97.

5. Dearfield, K. L; Cimino,M. C; McCarroll,N .E; Mauer,I; Valcovic, L. R, 2002 Genotoxicity risk assessment: a proposed classificationstrategy, Mutat. Res., 521,121-135.

6. Flora, S, De; Benniceli, C and Bagnasco, M, 1994 Genotoxicity of mercury compounds: A review .Mutat Res., $317: 57$.

7. Gravato, C; Santos, M. A,2013 Genotoxicity biomarkers' association with B[a]P biotransformation in Dicentrarchuslabrax L. Ecotoxicology and Environmental Safety. 55,352-358.

8. Grover, I, S. and Kaur, S, 1994 Genotoxicity of wastewater samples from sewage and industrial effluent detected by the Allium root anaphase aberration and micronucleus assays. Mutat Res. 26, 183-188.

9. Heddle, J. A; Cimino, M. C; Hayashi, M; Romagna, F; Shelby, M.D; Tucker, J.D; Vanparys, P.H. And MacGregor, J. T,2001 Micronuclei as an index of cytogenetic damage: past, present, and future. Environmentaland Molecular Mutagenesis.18, 277291

10. Karabay, N. U;Oguz, M. G,2005 Cytogenetic and Genotoxic effects of the insecticides, imidacloprid and methamidophos. Genet. Mol. Res. 4(4), 653-662.

11. Shah Mayur C;Shilpkar Prateek, G. and Acharaya Pradip, B,2008 Ecotoxicological Journal of Chemistry. ,5(3), 437-441.

12. Pacheco, M., Santos, M.A, 1999 Biochemical and genetic responses of adult eel (Anguilla anguilla) to resin acids and pulp mill effluent: laboratory and field experiments. Ecotoxicol. Environ. Saf., 42, 81-93.

13. Schmid, W, 1975 The micronucleus test. Mutat Res .31, 9-15.

14. Schmid, W, 1976 The micronucleus test for cytogenetic analysis, in: A. Hollaender (Ed.), Chemical Mutagens: Principles and Methods for their Detection, Plenum Press, New York, 4, 31-53.

15. Talukdar, D. I. B. Y. E. N. D. U., and T. U. L. I. K. A. Talukdar. "Catalase-deficient mutants in lentil (Lens culinaris Medik.): Perturbations in morpho-physiology, antioxidant redox and cytogenetic parameters." International Journal of Agricultural Science and Research 3.2 (2013): 217-232.

16. Tice, R.R;Shelby, M.D, 1994 Report of in vivo subgroup. Mutat. Res. 312, 287-292.

17. Report of the JACVAM initiative international pre-validation studies of the in vivo rodent alkaline comet assay for the detection of genotoxic carcinogens, 2013.

18. Fenech, M; Kirsch-Volkders, M; Natarajan, A.T; Surralles, J; Crott, J.W and Parry, J, 2011,Molecular mechanisms of micronucleus, nucleoplasmic bridge and nuclear bud formation in mammalian and human cells. Mutagenesis, 26, 125-32.

19. BALWAN, WAHIED KHAWAR, et al. "Cytogenetic Investigation of Cases with Primary Amenorrhea in Jammu Region of Jammu and Kashmir." International Journal of Zoology and Research (IJZR) 10.2 (2020): 1-8.

20. Bonassi, S; EI-Zein, R; Bolognesi, C and Fenech, M, 2011 Micronuclei frequency in peripheral blood lymphocytes and cancer risk: evidence from human studies. Mutagenesis, 26, 93-100. 
21. REGMI, BINOD, and BASANTA RAJ WAGLE. "HABITAT TYPE AND CLIMATIC ZONE CORRELATE WITH GENOME SIZE VARIATION IN OSTEICHTHYES FISHES." International Journal of Zoology and Research (IJZR) 7.1, Feb 2017, 7-12

22. Leopardi, P; Cordelli, E; Villani, P; Cremona, T.P; Conti, L and De Luca, G, 2011 Assessment of in vivo genotoxicity of the rodent carcinogen furan: evaluation of DNA damage and induction of micronuclei in mouse spleenocyte. Mutagenesis, 25, 5762.

23. Montano-Soto, Tatiana, Evarista Arellano-García, and L. Camarena-Ojinaga. "Genotoxic biomonitoring and exposure to pesticides in women laborers at maneadero valley in Baja California, Mexico." International Journal of Applied and Natural Sciences 3.2 (2014): 89-96.

24. Rothfuss, A; O'Donovan, M; De Boeck, M; Brault, D; Czich, A and Custer, L 2010 Collaborative study on fifteen compounds in the rat liver Comet assay integrated into 2 and 4weeks repeat dose studies.Mutat. Res. 702, 40-69.

25. Chen, W; Gao, J; Huang, J; Wang, B; Deng ,S; Yu, G, 2016 Fate and removal of typical pharmaceutical and personal care products in a waste water treatment plant from Beijing: A mass balance study. Front Environ. Sci. Eng, 10, 491-501.

26. CHAUHAN, MANISHKUMAR P., et al. "Characterization of Rhizobium Isolates from Sesbania Rhizosphere and their Role in Bioremediation of Glyphosate and Monocrotophos." International Journal of Applied and Natural Sciences. 6 (4): 1122 (2017).

27. Khanm, U.S; Masul, A.L; Khurshed, T; Chakma, U, 2018 Antibiotics prescription pattern in rural area of Bangladesh, Across sectional study in Debidwar Upasila of Camilla district. Int. J. Pharm. Sci, 10, 36-40.

28. Li, S.W; Lin, A.Y, 2015 Increased acute toxicity of fish caused by pharmaceuticals in hospital effluents in a pharmaceutical mixture and after solar irradiation. Chemosphere, 139; 190-196.

29. Minovski, N; Sacan, M.T; Emino, Lu E.M; Erdem, S.S; Novi, M, 2019 Revisiting fish toxicity of active pharmaceutical ingredients: Mechanistic insights from integrated ligand-/ structure based assessments on acetylcholine esterase. Ecotoxicol Environ Saf., 170, 548-558.

30. Sharma, M; Chadda, P, 2017 Widely used non-ionic surfactant 4-nonylphenol: Showing genotoxic effects in various tissues of Channa punctatus. Environ. Sci. Pollut. Res.Int., 24, 11331-11339. 